\title{
Copyright for the Digital Age - A Call for Legislative Reversibility
}

\author{
Felix Oberholzer-Gee ${ }^{\mathrm{b}}$
}

JEL-Classification: L51, O34, O38

Keywords: Copyright, Creative Industries, Regulation

\section{EU Copyright Directive}

On 12 September 2011, the Council of the European Union extended the term of protection of the rights of performers within the European Union from 50 to 70 years (Council of the European Union, 2011). The vote was not close. 17 members representing 255 votes supported the extension of copyright terms; eight members representing 76 votes - these included Sweden, the Netherlands, and a good number of Eastern European Countries - rejected the measure. Performers, the Council argued, "... generally start their careers young and the current term of protection of 50 years applicable to fixations of performances often does not protect their performances for their entire lifetime" (EUROPEAN UNION, 2011). A majority of the European Parliament and the Council accepted this line of argument. Is it sound?

Economists tend to think of copyright as striking a balance between the incentives to create, distribute, and perform new works (Sмітн, 1896) and the welfare losses that result if we grant creators, distributors, and performers market power (Marshall, 1890). From an economic perspective, protecting the incomes of ageing stars is perhaps a noble social goal. But copyright is not obviously the right instrument to achieve it. In this note, I will argue that copyright extensions such as the recent EU effort suffer from three shortcomings. They neglect the original intent of copyright; they suffer from a narrow view of markets that underestimates their ability to finance the creation of new works; and they are blind to the political consequences of granting too much protection to creators and performers.

a This article closely follows the keynote address that I gave at the annual conference of the Swiss Society of Economics and Statistics in June 2011. I would like to thank Laura Vélez Villa for excellent research assistance.

b Harvard Business School, 213 Morgan Hall, Soldiers Field, Boston MA 02163. E-mail: foberholzer@hbs.edu. 
To correct the current trend towards ever stronger protection of intellectual property (IP) rights and realign IP and social welfare, I propose an approach lagging regulation - that reflects the real uncertainty and political economy of granting IP. Lagging regulation starts from a premise that lawmakers, faced with major technological shifts, cannot anticipate the appropriate level of protection. IP rights will sometimes be too strong, sometimes too weak. If lawmakers are often wrong, an approach that allows them to reverse policy is highly desirable. Lagging regulation represents such an approach.

\section{Pirates at the Gates}

The call for extra protection of artists' and publishers' rights reflects in good part declining industry sales as well as concerns about the rampant piracy of music, videos, games, software, and books. Ferguson (2006) estimates that more than $60 \%$ of Internet traffic consists of file sharing on peer-to-peer networks that facilitate the transfer of copyrighted materials without compensating authors and publishers. These networks have become ever more powerful, allowing consumers to download even a high-quality movie file in only a few hours (for a brief history of file sharing and information on the underlying technology, see Oberholzer-Gee and StrumpF, 2010). Without a doubt, file sharing has considerably weakened copyright protection, but the effect of file sharing on the sales of entertainment products is fiercely contested. Some studies find significant negative effects (RoB and Waldfogel, 2006; Liebowitz, 2008), while others come to opposite conclusions (Oberholzer-Gee and Strumpf, 2007; Smith and Telang, 2010). The debate, fascinating to econometricians and applied economists, is of little help to regulators and policy makers who need to determine whether to intervene.

Is a decline in sales of recorded music, if it is, in fact, due to file sharing, a reason to strengthen copyright protection? This is the wrong question to ask. Copyright is meant to encourage the supply of creative works, not to guarantee specific sources of income. This is the first sense in which the European Commission's intervention is misguided. In order to determine whether an extension of copyright terms is desirable, we have to ask three questions: Is there too little music today? Will artists write and record more of the undersupplied type of music if they know their rights will expire in 2081 instead of 2061? And how

1 Discounted at $10 \%$, an annual payment of $€ 1,000$ in the years from 2061 to 2081 is valued at less than $€ 70$ today. By this measure alone, the incentive effect of the EU copyright term extension appears to be fairly small. 
does the value of these additional works compare to the loss in welfare resulting from higher prices or lower profits? "Yes", "yes", and "favorable" are the answers that justify extended copyright terms.

I begin with the current supply of music. To answer the question whether weaker copyright diminished the availability of music, it is helpful to turn to aggregate production statistics. In Germany, for instance, the number of available recordings increased from 157,237 in 2002 to 237,467 in 2009 (Bundesverband Musikindustrie, 2009). During the same time period, however, the annual number of new releases fell from 44,265 to 40,741, raising a concern that shrinking sales might have dampened industry incentives to release new works. In Germany, as elsewhere, there are two difficulties with these industry measures of supply. First, they tend to disregard smaller, independent labels. And it is these labels, we suspect, that produce a larger number of new recordings in the digital era. In fact, using a comprehensive measure of new releases, HANDKE (2010) documents that there is no significant change in the long-term upward trend in the supply of new works to the German market. Similar observations hold elsewhere. In the United States, the number of new albums increased from 35,516 in 2000 to 75,000 albums (including digital albums) in 2010 (NIELSEN SoundSCan, 2010). In film, the worldwide number of feature films produced each year rose from 3,807 in 2003 to 5,133 in 2008 (SCreen Digest, 2004 and 2008). In books, the number of new titles and editions increased from 247,777 in 2002 to $1,335,475$ in 2009 .

Aggregate production statistics tell us little about the quality of the works that are released. One concern is that the digitization of the music business might have reduced the number of high-quality, label-released products and led, at the same time, to a flood of low-quality releases for which there is little demand. In a clever paper, WALDFOGEL (2011) tries to get at this issue by comparing changes in three indices of music quality over time: critics' retrospective lists, music sales, and airplay. In all three measures, there is no evidence of a reduction in the quality of music since the advent of file sharing. In fact, there is some indication that music has been of higher quality in more recent years.

If there is no concern with the supply of new works, the case for copyright extensions falls apart. Before we conclude that all is well, however, it is important to understand why artists continue to produce new works. 


\section{Shifting Revenue Pools and Intrinsic Motivation}

Against the backdrop of falling record sales, the increase in the available number of quality recordings may seem surprising. Dim views of the future of music, however, are mostly the result of an overly narrow view of the industry, a view that neglects the importance of complementary products. As basic economic reasoning suggests, a fall in the price of music due to weaker copyright will increase the demand for its complements. Important complements include the concert business, home stereo and personal computer equipment as well as music-related merchandise. The digitization of music resulted in a shift in revenue pools, away from music towards its complements. For example, recorded music revenues in Sweden collapsed in the 2000-2008 period, falling by more than 50\% (JoHansSON and LARSSON, 2009). However, overall industry revenues in that same time period were basically flat, in part because revenues from concerts increased substantially (see Figure 1). Johansson and Larsson estimate that the share of industry revenue that accrued to artists increased by $34.6 \%$ in the period since 2000 . The observation of rising artist incomes in Sweden is consistent with observations in the U.K. (TimesLabs, 2009) and the United States where higher ticket prices as well as more frequent touring led to rising artist incomes (MORTIMER and Sorenson, 2005).

Companies outside the traditional music industry benefitted from the decline in the price of music as well. For instance, Leung (2008) estimates that piracy increases the sale of iPods by roughly $20 \%$. Comparing the number of iPods and songs that Apple sold, only a small fraction of the capacity of these digital music players is taken up by content purchased from iTunes (Yoffie and Kim, 2010). A significant portion of the drive of a typical device, one would suspect, is filled with pirated materials. Similarly, it seems likely that the availability of cheap content drives broadband adoption and, as a result, the sale of Internetrelated equipment.

As this discussion suggests, policy makers who accept the decline in the sale of music as an indication for the need to strengthen copyright suffer from toonarrow a view of markets. As it turns out, businesses other than the traditional publishers are quite capable of providing incentives for the creation of new works. As piracy weakens copyright and lowers the effective price of music, these incentives will become stronger, protecting the supply of music.

A second reason why copyright may have a muted influence on the creation of new works is that financial incentives play a minor role in many creative industries. For example, in a Pew study of 2,755 musicians and songwriters (MADDEN, 2004), two thirds of respondents said they earned less than twenty 
Figure 1: Music Industry Revenues in Sweden (2000-2008)

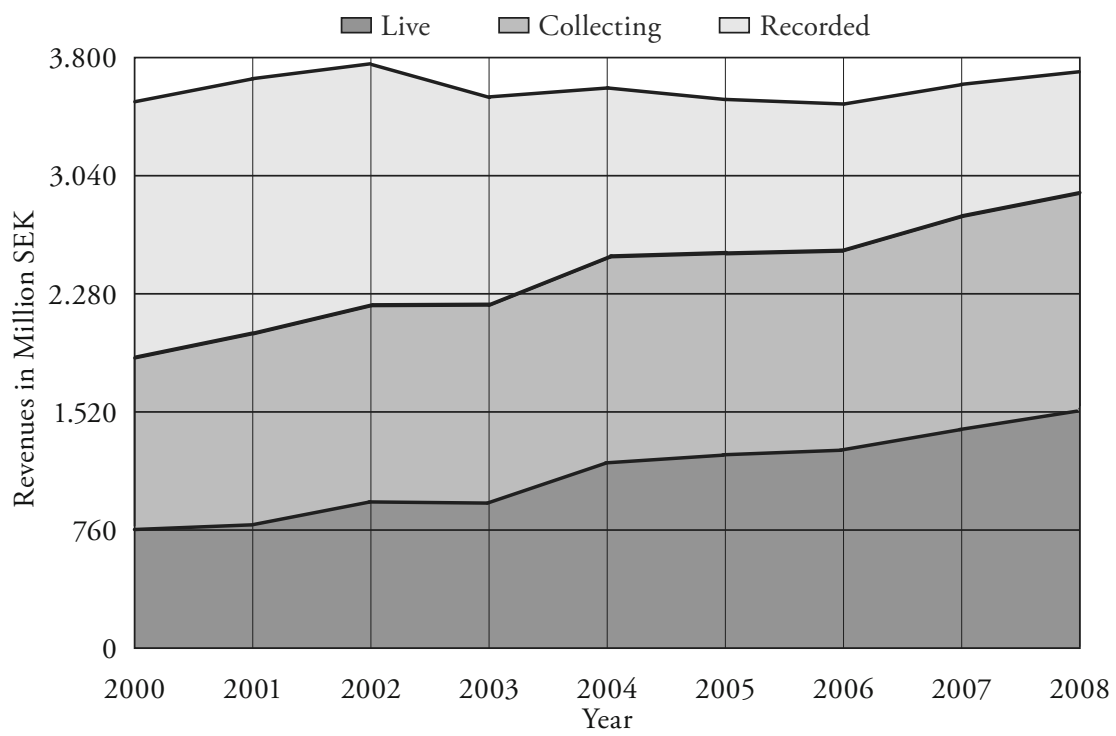

Source: Johansson and LARSSON (2009)

Note: "Live" refers to the live concert business. "Collecting" is the revenue collected by IFPI (International Federation of the Phonographic Industry) and SAMI (Swedish Artists and Musicians Interest Organization). IFPI Sweden is collecting for the producers (from radio and TV) and SAMI for the performers (from public performances). "Recorded" is the revenue from recorded music and includes digital sales.

percent of their income from music. The small income share does not mean that musicians spend little time on their craft. Even among those who spent at least thirty hours a week on music-related activities, only $22 \%$ derived at least fourfifths of their income from music (for a broader discussion, see OBERHOLzerGee and StrumpF, 2010).

There are two leading theories that can explain why artists create new works in the absence of strong financial incentives. A first holds that artists are largely intrinsically motivated. Musicians take pleasure from many aspects of their lifestyle, in particular from creating and performing music. An alternative explanation is that popular music is a tournament in which a few artists collect most of the economic rewards. This view is rooted in the theory of superstars (Rosen, 1981). Under the superstar theory musicians essentially consider their job to be 
a lottery. They perform and create new works because of some small chance to become a superstar.

Under these two views, copyright plays a smaller role in the creative industries than elsewhere in the economy. Intrinsically motivated musicians pay little attention to financial incentives. And would-be superstars are appropriately motivated as long as the expected income of being a star exceeds the opportunity cost of working for breakthrough success. Last year, U2 earned \$195 million, followed by Bon Jovi with $\$ 125$ million (O’Malley Greenburg, 2011). Because the sale of CDs played a smaller role for such leading artists even prior to the advent of file sharing and weaker copyright (KRUEGER, 2005), the tournament incentives are likely to stay intact even if most content is available for free.

\section{Lagging Regulation}

The view that emerges from these considerations points to a complex task for lawmakers and regulators. Weaker protection for intellectual property may or may not be a reason to act depending on the viability of the markets for complements as well as the importance of superstar dynamics and intrinsic motivation. It is of course difficult to anticipate whether markets for complements will be viable and whether the best-paid stars will continue to earn sums that motivate the broad availability of creative works. In view of these difficulties, I propose an approach that is based on simple reversibility logic. Lawmakers will make mistakes, sometimes extending copyright terms too far, sometimes offering too little protection. What matters are not the mistakes but whether or not they can be corrected. For some inappropriate levels of copyright protection, the adjustment is easy. For instance, if copyright is too weak and the supply of new works begins to decline visibly, stronger protection can move the industry to a more appropriate level of creative activity. By contrast, legislative mistakes are much harder to correct if they create constituencies that benefit from an inappropriate level of protection. For example, once copyright protection is too strong, the coalition of businesses and individuals that benefit from these protections will lobby hard against any socially desirable weakening of copyright. Legislative reversibility is at risk in this latter case.

To increase the likelihood of achieving an appropriate level of protection, Table 1 lays out a simple, rule-based approach. The rule takes into account the considerable uncertainty surrounding intellectual property rights decisions as well as the political economy of regulatory reversibility. I distinguish two types of shocks (e.g., changes in technology such as the advent of file sharing). They 
can weaken or strengthen the effective protection of intellectual property rights. And I take into account the current level of protection. Under the proposed rule, lawmakers would commit to doing nothing in four of the six cases. Consider the logic for the cell "technology weakens copyright" / "current activity appropriate" which is perhaps close to the current situation. If lawmakers do not act and markets for complements turn out to be less viable than we had hoped, a subsequent strengthening of copyright can move the economy closer to the desirable state. In this scenario, lawmakers make a mistake - they are too optimistic about the market for complements - but the mistake can be corrected. By contrast, a rule that asks lawmakers to act now in anticipation of a drop in the supply of new works is less reversible. If lawmakers strengthen copyright and markets for complements turn out to be weak, all is well. But if complements provide sufficient incentives, the copyright extension turns out to be a mistake, a mistake that cannot easily be corrected because artists and labels will defend their recentlyacquired rents.

Table 1: Regulatory Approaches to Property Rights

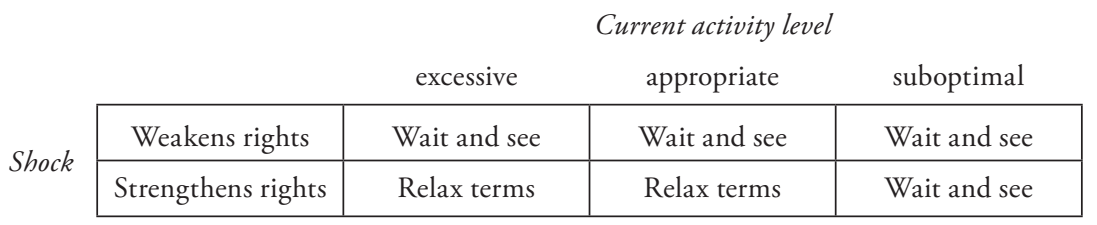

There are only two situations in which this approach recommends acting in anticipation of the impact of shocks. If technological shocks strengthen copyright, it is difficult to foresee the resulting changes in the supply of new works. In this case, however, lawmakers are encouraged to relax copyright terms before the consequences of the shock are visible. The logic is again based on the strength of interest groups. Excessive protection is difficult to reduce once artists begin to benefit from stronger-than-optimal rights.

Lagging regulation of the type proposed here, I believe, is an important tool to achieve a level of IP protection that reflects the social benefits and costs of property rights. The current approach, which seeks to adjust the level of protection in anticipation of changes in the economic environment, has three serious shortcomings. It typically neglects the original intent of copyright which is to safeguard the supply of new works, not to guarantee income from a specific source; it suffers from a rigid view of markets that systematically underestimates 
the importance of complements, superstar effects and intrinsic motivation in the creative industries; and it is blind to the political consequences of granting too much protection to creators and performers. As a result, copyright has evolved in only one direction over the past 200 years: ever stronger protection. It is high time, I believe, to break the cycle.

\section{References}

Bundesverband Musikindustrie (2009), „Musikindustrie in Zahlen 2009“, Available at http://www.musikindustrie.de/publikationen0/, accessed in October 2011.

Council of the European Union (2011), "New Rules on Term of Protection of Music Recordings", Press Release 13972/11-PRESSE 303. Brussels, 12 September.

European Union (2011), "Directive 2011/77/EU of the European Parliament and of the Council", Official Journal of the European Union, 11/10/2011, L265/1.

Handke, Christian (2010), "The Creative Destruction of Copyright - Innovation in the Record Industry and Digital Copying", Erasmus University Rotterdam Thesis, available at http://ssrn.com/abstract=1630343, accessed in October 2011.

Johansson, Daniel, and Markus Larsson (2009), "The Swedish Music Industry in Graphs Economic Development Report 2000-2008", available at http:// www.trendmaze.com/media/1038/swedish_music_industry_2000-2008.pdf, accessed in October 2011.

Leung, Tin Cheuk (2009), "Should the Music Industry Sue Its Own Customers? Impacts of Music Piracy and Policy Suggestions", University of Minnesota Working Paper, available at http://www.ihome.ust.hk/ fnjuwong/ paper/i-Podandpiracy.pdf, accessed in October 2011.

Liebowitz, Stanley J. (2008), “Testing File Sharing's Impact on Music Album Sales in Cities", Research Note, Management Science, 54(4) pp. 852-859.

Krueger, Alan B. (2005), "The Economics of Real Superstars: The Market for Rock Concerts in the Material World", Journal of Labor Economics 23(1), pp. 1-30

Madden, Mary (2004), "Artists, Musicians and the Internet", Pew Internet \& American Life Project, available at http://www.pewinternet.org/Reports/2004/ Artists-Musicians-and-the-Internet.aspx, accessed in May 2011.

Marshall, Alfred (1890), Principles of Economics, London: Macmillan and Co. 
Mortimer, Julie Holland, and Alan Sorensen (2005), "Supply Responses to Digital Distribution: Recorded Music and Live Performances", Harvard University Working Paper.

O’Malley Greenburg, Zack (2011), "The World's Highest-Paid Musicians", Forbes, 15 June, available at http://www.forbes.com/sites/zackomalleygreenburg/2011/06/15/the-worlds-highest-paid-musicians/, accessed in October 2011.

Oberholzer-Gee, Felix and Koleman Strumpf (2007), "The Effect of File Sharing on Record Sales: An Empirical Analysis", Journal of Political Economy, 115(1), pp. 1-42.

Rob, Rafael, and Joel Waldfogel (2006), "Piracy on the High C's: Music Downloading, Sales Displacement, and Social Welfare in a Sample of College Students", Journal of Law and Economics, 49(1), pp. 29-62.

Rosen, Sherwin (1981), "The Economics of Superstars", American Economic Review, 71, pp. 845-858.

Smith, Adam (1896), Lectures on Jurisprudence. R. L. Meek, D. D. Raphael and P. G. Stem (eds), Oxford Univ. Press 1978 (1896).

Smith, Michael, and Rahul Telang (2010), "Competing with Free: The Impact of Movie Broadcasting on DVD Sales and Internet Piracy", MIS Quarterly, 33(2), pp.321-338.

Waldfogel, Joel (2011), "Bye, Bye, Miss American Pie? The Supply of New Recorded Music Since Napster”, NBER Working Papers, w16882.

Yoffie, David B., and Renee Kim (2010), "Apple Inc. in 2010", Harvard Business School case 710467, Boston: Harvard Business School Publishing.

\section{SUMMARY}

Policymakers tend to adopt too narrow a view of the creative industries when determining the desirability of copyright protection. In these industries, authors will often create new works despite weak protection. As recent developments in the music industry illustrate, markets for complements alone can be sufficiently lucrative to entice artists to remain active even when copyright is seriously weakened. However, the value of complements is difficult to forecast. As a result, lawmakers will often set inappropriate copyright terms. In this note, I call for an approach to copyright legislation that makes it feasible to correct these unavoidable mistakes. 